\title{
Plenitud de Amado Nervo: ¿prosa aforística o poemas en prosa?
}

\author{
Ana Vigne Pacheco \\ Universidad de Toulouse \\ Le Mirail, Francia
}

En el mes de octubre de 1907, once años antes de la publicación de Plenitud, Nervo escribió en Madrid una corta página autobiográfica, "Habla el poeta". ${ }^{1}$ Después del relato de una anécdota de su infancia evocando sus primeros balbuceos literarios, el autor justifica la irregularidad cualitativa de su producción periodística y poética, de la cual se muestra poco satisfecho. En el primer caso, la culpa se la achaca al escaso tiempo que el cronista había podido dedicar a sus artículos; en cuanto a los defectos en su poesía, se los atribuye más bien a su poca experiencia y a su juventud. Expresa igualmente sus arrepentimientos de no haber podido escribir un libro que hubiera sido, hasta cierto punto, una síntesis de su obra literaria y de su experiencia vital:

He hecho innumerables cosas malas en prosa y verso, y algunas buenas; pero sé cuáles son unas y otras. Si hubiese sido rico, no habría hecho más que las buenas, y acaso hoy sólo se tendría de mí un pequeño libro de arte consciente, libre y altivo. ¡No se pudo! Era preciso vivir en un país donde casi nadie leía libros, y la única forma de difusión estaba constituida por el periódico. De todas las cosas que más me duelen, es ésta la que me duele más; el libro breve y precioso, que la

1 Salvo indicación contraria, las referencias de los textos citados remiten a la edición que indicaremos a continuación con las iniciales OCAN, seguidas de los números de los tomos y de las páginas, ya sea en el cuerpo mismo del texto, ya sea entre paréntesis, al final de la cita. 
vida no me dejó escribir: el libro libre y único (OCAN II: 1065. Cursivas mías).

Plenitud bien podría ser ese libro soñado en la medida en que lo escribió pausadamente, sin las premuras de la producción periodística y cuando ya se trataba de un autor consagrado que no le temía ni a una mala crítica ni a un fracaso comercial. Sin embargo, nada permite corroborar esta afirmación, ya que Nervo nunca se pronunció claramente sobre su forma y es imposible saber si pensaba en una selección de poesías o de prosas. Así pues, en el estudio preliminar que Francisco González Guerrero le dedica a la prosa de Nervo en su edición de las Obras completas, piensa que Plenitud sería el libro que sustituyó a otro proyecto del poeta, expresado en estos términos:

Voy a hacer un devocionario lírico-recogió sus palabras un escritor de Castilla-, un libro de oraciones en verso, con aprobación de la censura eclesiástica, y, si es posible, con la concesión de algunas indulgencias para los devotos que lo leyeren (OCAN I: 28. Cursivas mías).

Y González Guerrero añade a propósito de esta declaración:

El proyecto quedó incumplido y acaso favoreció al poeta su abandono, porque entonces no estaba del todo limpio de esnobismo satánico ni había llegado a la plenitud de su pensamiento religioso. Sin embargo, no realizada la idea primitiva, reapareció más tarde transformada en un breviario de consolación filosófica y de incitación al perfeccionamiento espiritual. Plenitud es el título inmejorable de esta pequeña obra áurea, digna de un poeta místico y de un pensador estoico (OCAN I: 28. Cursivas mías).

Esta opinión de González Guerrero parece indicar que a fin de cuentas, el problema del género literario de Plenitud es secundario, pues se trata ante todo de un libro cuyos objetivos poéticos y filosóficos aparecían íntimamente vinculados, de tal manera que Nervo pensó escribirlo a ratos en verso, y a ratos en prosa poética o aforística.

La misma interpretación la encontramos en la edición del traductor estadunidense, William F. Rice, presidente del Departamento de Estudios Hispánicos de la Universidad de California del Sur, quien tradujo y publicó el libro en Los Ángeles en 1928. Las frases siguientes, 
que cubren casi la totalidad de la portada, son enteramente de su invención e introducen la obra para el público de Estados Unidos, tratando de despertar su interés por el mensaje poético-filosófico del autor mexicano:

Do you fear Death? You will not after you learn the beautiful secret of this inspiring life.

Not a book of Devotion, but one that inspires to noble living.

The Philosophy of Life, out of the life of a Philosopher.

Pointed Paragraphs that scintillate like the stars of a winter night ${ }^{2}$ (Nervo, 1928).

Por consiguiente, Nervo parecía cultivar cada vez más esta contaminación entre verso y prosa, herencia que los románticos legaron a los modernistas, como lo señala José Ricardo Chaves en su estudio sobre el relato finisecular:

La evanescencia entre prosa y poesía es algo que viene desde los primeros románticos, que pusieron en duda la neoclásica separación de géneros literarios y propugnaron más bien por su abolición, con la creación de estados híbridos como el poema en prosa o la prosa poética, o bien el teatro simbolista (José Ricardo Chaves, 1999: 23).

En el último libro que el poeta publicó antes de morir en 1919, El estanque de los lotos, éste subraya su posición ambigua frente a la división genérica entre prosa y poesía, en el poema liminar:

Lector mío, estos versos, que son prosa (rimada), Llegan a tu alma humildes y sin pedirte nada.

No quieren tus elogios... Mas sería de mi gusto

Que pudieses leerlos al terminar el día,

A los fulgores cárdenos de algún poniente augusto,

Que fuese como el marco de mi filosofía...

(OCAN II:1763. Cursivas mías.)

\footnotetext{
2 [¿̨Tienes miedo a la muerte? No lo tendrás después de que aprendas el bello secreto de esta vida inspirada.

No es un libro de devoción sino uno que inspira a la vida noble.

La filosofía de la vida, que surge de la vida de un filósofo

Parágrafos punteados que titilan como estrellas de una noche invernal].
} 
Y más adelante, en otro poema del mismo libro, "No más música", nombre tan evocador para nuestro propósito porque rechaza la estética de Verlaine de los comienzos del modernismo, para abrirle campo a una poesía desencarnada y muy cercana a la prosa, Nervo remite sus dones poéticos entre las manos de Dios y proclama:

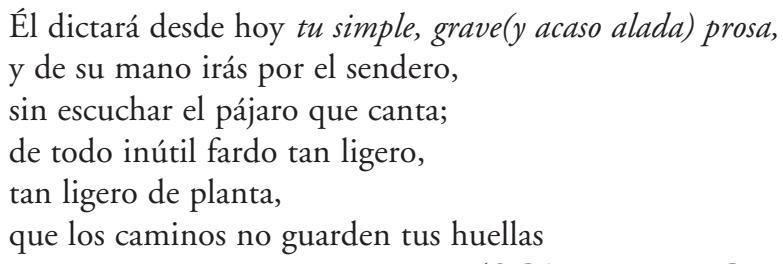

(OCAN II: 1789. Cursivas mías).

Lo que se desprende entonces de estos textos tardíos de la obra de Nervo es el rechazo de los oropeles modernistas de sus mocedades y la voluntad de simplificar al máximo la expresión literaria. Simplificación que, como lo había señalado Alfonso Reyes, le conducía inexorablemente al silencio: "Por momentos me ha parecido que Nervo acabará por preferir el balbuceo a la frase, que se encamina al silencio. Su silencio sería, entonces, la corona de su obra" (29-30). Por lo demás, dicho despojamiento podría explicar su tentación cada vez mayor de escribir aforismos, ya sea como sentencias en prosa, ya sea como poemas cortos. De manera que ambos géneros cohabitan hasta el final en su obra, a veces confundiéndose.

Algunos críticos establecen un paralelo entre el libro en prosa y sus poemarios Serenidad (1914) y Elevación (1917); sobre todo con este último, que viene a ser una suerte de gemelo poético de Plenitud. Por otra parte, la opinión de González Guerrero no suministra una respuesta muy clara a la difícil pregunta de la clasificación genérica del último libro, pues lo llama "haz poemático", con un adjetivo que se aplica más frecuentemente a la prosa que al verso aunque, en cierta época, "poético" y "poemático" fueran sinónimos:

Como estos dos libros, es un haz poématico, pero sin el rigor de las sílabas contadas: Plenitud se halla vertido en prosa clara, fluente, dulce y apaciguadora; prosa de "diafanidad cristalina y puro esplendor de espíritu” (Francisco González Guerrero, OCAN I: 28. Cursivas mías). 
La semejanza de temas y tono entre Elevación y Plenitud autoriza perfectamente dicho acercamiento, sobre todo al leer el texto breve que clausura el poemario, "Amén":

Lector: Este libro sin retórica, "sin procedimiento", sin técnica, sin literatura, sólo quiso una cosa: elevar tu espíritu. ¡Dichoso yo si lo he logrado! Diciembre de 1916 (OCAN I: 1760.)

Así pues, a comienzos de $1918,{ }^{3}$ Amado Nervo va a publicar en Madrid, en la editorial Tipografía Artística un libro delgado, de formato pequeño, con sobrias tapas grises. Compuesto por sesenta textos breves en prosa, ya que los más largos no excedían página y media, se intitulaba: Plenitud. Sus cortos capítulos estaban formados por párrafos breves, compuestos a veces por una sola frase, y daban la impresión de ser estrofas poéticas o sentencias. La disposición tipográfica acentuaba a su vez dicha impresión, ya que cada texto se hallaba impreso en el centro de la página como se suele hacer con los poemas. De manera que los primeros lectores practicaron una lectura más cercana a la de un libro de máximas o a un poemario en prosa, que a la de un ensayo filosófico o de un texto narrativo.

La primera edición de Plenitud se presenta, con carátula gris y letras negras, salvo el título que se destaca con letras rojas en la parte superior. El nombre de su autor aparece dos veces: primero completo, y luego bajo la forma de un ex libris, que representan las iniciales de Nervo en el interior de un cuadrado negro, que no es más que la reproducción del monograma que éste había mandado grabar sobre un anillo. ${ }^{4}$ Vienen luego el lugar y la fecha de publicación, "Madrid1918", y una frase corta que sirve de envío para los futuros lectores: "Esta es mi riqueza: toda para ti". Se trata, entonces, de una portada

\footnotetext{
${ }^{3}$ La edición original no tiene fecha de publicación, pero los descendientes del escritor conservan un ejemplar con dedicatoria a su hija adoptiva, Margarita Dailliez: "Pour ma très chère Marguerite, petite compagne dans mon chemin -Amado- enero, 30/918”.

${ }^{4}$ He aquí el testimonio del señor Rafael Padilla Nervo, descendiente del poeta, que se encuentra en una carta que me dirigió el 11 de agosto de 2004: "En relación con el monograma que aparece en la portada de la primera edición española de Plenitud, éste es similar al del anillo, en oro recubierto de acero, que Nervo usaba y que se aprecia claramente en las conocidas fotografías tomadas al poeta en 1918 por el mexicano Lupercio". El monograma aparece por primera vez en la portada de Juana de Asbaje, publicado en 1910, y en la de Elevación, de 1917.
} 
sobria y austera, muy distinta de las hermosas carátulas ilustradas de los tiempos del modernismo triunfante. Por lo visto, su "pacto de lectura" dirige la recepción del libro hacia un tratado de sabiduría o de ejercicios espirituales, y la riqueza que en ella se encuentra no tiene nada que ver con la de las Perlas negras que, veinte años atrás, le habían procurado fama a su autor.

Por esos misterios de las editoriales y de las modas literarias, cuando Alfonso Reyes publicó el libro en 1920, en el tomo XVII de las Obras completas del recién fallecido poeta, su portada sufrió una transformación asombrosa. El dibujante Marco, ilustrador de esta nueva edición, presenta en la carátula a una mujer desnuda con los brazos en alto. Esta mujer se destaca sobre un fondo de luna llena, en la actitud de aquella ninfa del famoso cuadro de Ingres, La fuente. Sólo que, en lugar de verter el agua de un cántaro, un velo negro flota por detrás de sus espaldas, y una guirnalda, compuesta de motivos que tienen más de geométricos que de florales, desciende artísticamente a lo largo de su cuerpo, ocultando diestramente el sexo de la joven. Ambos, velo y guirnalda, terminan enlazados en la parte inferior, mientras las siluetas de unos árboles melenudos se perfilan sobre un cielo debidamente estrellado. Así, se ha pasado de la austera y sobria portada de la primera edición, aprobada por su autor, a una representación donde predominan el erotismo y la sensualidad más descarados. En cuestión de pocos meses, el dibujante interpreta el título Plenitud de una manera muy diferente, e induce a los futuros lectores a establecer un "pacto de lectura” totalmente distinto al de los lectores anteriores. ¡Cabe preguntarse, maliciosamente, si no fue el epígrafe latino sacado de San Pablo y de su primera carta a los Tesaloniciences, semper gaudere (iEstad siempre gozosos!), el que inspiró a Marco tal representación!

Esta transformación radical tiende, por otra parte, a confirmar la dificultad de la interpretación del texto de Nervo. ¿Se trata de un tratado filosófico para mejorar la condición humana y meditar sobre el amor al prójimo y a Dios, o más bien de una incitación a disfrutar "los alimentos terrenales" como los llamara André Gide en un libro famoso? En todo caso, el recorrido textual parece indicar una búsqueda que debe culminar con un perfecto desarrollo personal, pues se inicia con "En ti está el secreto" y concluye con "Alégrate", bajo los auspicios del epígrafe bíblico citado. 
En el caso de Nervo, es justamente su gusto por la brevedad lo que lo llevará hacia la escritura aforística. No sólo la defendió repetidas veces en su obra, sino que también la cultivó ya sea en prosa o en verso, como se puede comprobar en las dos secciones intituladas Pensando que aparecen en sus Obras completas (1991). La primera, en prosa, se encuentra junto con Plenitudy Las ideas de Tello Téllez, y la segunda, en verso, al final del segundo tomo. Alfonso Méndez Plancarte presenta esta segunda colección así: "Esta miscelánea de madrigales, epigramas, sentencias y aun simples fragmentos - a menudo meros dísticos o monósticos- apareció en el tomo 27 de la Biblioteca Nueva"5 (OCAN II: 1895).

Por consiguiente, estas formas breves se mantuvieron a lo largo de toda la producción de Nervo, con tendencia a ir aumentando hacia el final. Esto corre parejo con una progresiva depuración de su escritura, tanto en la poesía como en la prosa, que parece llevar al poeta a expresar lo esencial de manera cada vez más concisa. Alfonso Reyes destacó con mucha pertinencia dicho aspecto en los diferentes estudios que dedicó al hombre y a la obra, como en el caso del ensayo sobre Serenidad:

Su maestría de palabra viene de cierta depuración de las ideas, y tiene por caracteres dominantes la brevedad y la transparencia. [...] El escritor de prosa que hay en Amado Nervo ha influido al fin en el poeta. Hace años que viene desarrollando en páginas breves ciertas ideas de ensayista curioso. [...] En otros el arte disfraza. En él, desnuda (Reyes 1937: 21-33).

Ya en 1910, cuando publicó su libro Juana de Asbaje, Nervo intercala declaraciones que confirman ese deseo de simplicidad y de concentración, que lo alejan definitivamente del modernismo de su juventud, para llevarlo hacia una escritura sobria y, por decirlo así, ascética:

[...] ahora que, según Rubén Darío "he llegado a uno de los puntos más difíciles y más elevados del alpinismo poético: a la planicie de la

5 El volumen XXVII de las Obras completas de Nervo en la Biblioteca Nueva corresponde a El arquero divino, publicado en 1922, aunque fue escrito entre 1915 y 1918. 
sencillez, que se encuentra entre picos muy altos y abismos muy profundos"; ahora que no pongo toda la tienda sobre el mostrador en cada uno de mis artículos; ahora que me espanta el estilo gerundiano; que me asusta el rastacuerismo de los adjetivos vistosos, de la logomaquia de cacatúa, de la palabrería inútil; ahora que busco el tono discreto, el matiz medio, el colorido que no detona; ahora que sé decir lo que quiero y como lo quiero; que no me empujan las palabras sino que me enseñoreo de ellas; ahora, en fin, que dejo escuro el borrador y el verso claro, y llamo al pan, pan, y me entiende todo el mundo (1), ${ }^{6}$ seguro estoy de no incurrir en juicio temerario si pienso que alguno ha de llamarme chabacano [...] Pero, francamente, estoy fatigado del alpinismo, y ya que según el amable Darío ${ }^{7}$ llegué a la deseada altiplanicie, allí me planto, exclamando como el francés famoso: J'y suis, j’y reste (OCAN II: 466).

En 1917 publicará su ensayo "Brevedad", donde elogia todavía más esta característica de su escritura, preparando la llegada de Plenitud, un año más tarde.

\section{NerVo y El ELOGIO DE LA BREVEDAD}

El ensayo mencionado aparece en la sexta sección de las prosas de Nervo de la edición de 1991, en compañía de otros textos cuyo denominador común parece ser la reflexión filosófica. "Brevedad" se divide en dos partes separadas: la primera ilustra los méritos de la brevedad a través de un cuento de la tradición oriental, mientras que la segunda desarrolla las ideas de su autor al respecto, justificándolas por medio de ejemplos sacados de la cultura occidental al mismo tiempo que transmite su deseo de querer, a su vez, expresar lo esencial en un texto breve. El cuento está situado dentro de la tradición de los cuentos de las Mil y una noches, ya que su protagonista es nada menos que el califa de Bagdad:

Es bien sabida la historia de aquel califa de Bagdad que, deseoso de instruirse y no pudiendo llevar consigo en sus frecuentes viajes toda su

6 (1) "Llaneza, muchacho, que toda afectación es mala", decía maese Pedro a cierto chico que delante de Don Quijote explicaba los muñecos de un retablo.

7 Darío (1950: 589). 
biblioteca, pidió a los sabios de su reino que le condensasen hábilmente la ciencia entera de la Humanidad, en número tal de volúmenes que pudiesen cargarlo diez camellos (OCAN II: 849).

Más adelante, el califa quiere que le concentren la sabiduría en varios volúmenes que transportará un solo camello, y luego en un solo tomo que el soberano podrá hojear a su conveniencia y, por fin, en una sentencia única que condensará toda la sabiduría humana, para grabarla en la maravillosa esmeralda de su sortija:

Antes, pues, de la luna de abril, el lapidario real tenía en su poder la sentencia; antes de la luna de mayo, con los más finos y bellos caracteres, en la enigmática superficie verde de la gran esmeralda estaba grabada (pongo por caso, pues que la historia no ha dilucidado aún bien este asunto) la siguiente sentencia fulgurante y eterna: "Alá es grande. Ámale sobre todas las cosas... ¡Y no te fíes de las mujeres!" (OCAN II: 850).

Por medio de esta "peregrina historia", en la segunda parte del texto, un narrador personal va a discurrir sobre las ventajas de la brevedad, con un ligero toque de humor y de ironía, dirigido contra él mismo:

Cuando publiqué mi primera novela, El Bachiller, un crítico de Méjico, tras algunos juicios poco satisfactorios, concluía así:

"Por lo demás, la novela es breve [...] como el ingenio que la produjo." $\mathrm{Y}$ he perseverado en esta brevedad, en esta homeopatía intelectual, hasta hoy. [...] ¿Es un mérito la brevedad? [...]

Problemas formidables solicitan al hombre y a la mujer en el mundo moderno. Ni en la más apartada provincia se puede ya dedicar una vida al benedictinismo, y quien quiera decir algo útil, algo bello, algo noble, algo consolador a sus hermanos ha de decírselo brevemente (1). ${ }^{8}$ (OCAN II: 851. Cursivas mías).

La brevedad, entonces, puede servir para concentrar de forma lacónica conceptos esenciales para que el lector moderno, apresurado e

\footnotetext{
8 (1) De aquí en adelante aparece publicado bajo el título Elogio de la brevedad. Es la parte propiamente original de este ensayo (Nota de Alfonso Reyes en la edición de 1920: XXVI. 266. Desaparece en OCAN).
} 
impaciente, no se aburra mientras va leyendo un escrito corto, y se entere rápidamente de su mensaje. Idea que Nervo había expresado antes en El donador de almas (1899) ("Nuestra época es la de la nouvelle. El tren vuela [...] y el viento nos impide hojear los libros") (Nervo 1920: 79, pero que no basta para considerar su elogio de la brevedad como únicamente la preocupación de un periodista, esclavo de una literatura de consumo, rápida y eficaz. Pues Nervo cultivó y amó toda su vida esa forma de escritura, concisa y fragmentaria, que resumía bien su visión del mundo y de sus semejantes. Por lo tanto, en la continuación de su ensayo, trata de demostrar que de las grandes obras de nuestra cultura occidental, sólo se recuerdan algunas citas fundamentales, compendio de la creación y de la sabiduría humanas. De Shakespeare, el lector medio conoce algunas frases sin haber leído forzosamente todas sus piezas, y de la Biblia recordará algunas sentencias del Eclesiastés, unos versículos de los Salmos, el discurso amoroso del Cantar de los Cantares y las lamentaciones de Job. Lo mismo sucede con la sabiduría hindú contenida en algunos pasajes del Bhagavad-Gîtâ, en las parábolas de Buda o en un número restringido de definiciones de los Upanishads. Concluyendo el ensayo con un tono amistoso que incita al lector a cultivar también la brevedad:

De suerte que, amigos míos, los que sabemos poco, los que podemos decir poco, alegrémonos, regocijémonos de haberlo dicho con una concisión fuerte y piadosa al propio tiempo, con aquella concisión que el perfecto Flaubert, de sobriedades numismáticas, exigía al frondoso Maupassant joven. [...]

Habremos sido como esos cocuyos de mi tierra, que fulguran misteriosamente en la noche, con fosfórea y furtiva luz, y a quienes no siempre el caminante puede seguir con la vista.

Brillaron un instante y pasaron; mas el trémulo relámpago de oro bastó al viajero para ver la bifurcación del camino, iy ya no se perdió en medio de la noche! (OCAN II: 852.)

Estas últimas frases reajustan el concepto de brevedad en su creación literaria, no sólo por la alusión a Flaubert, sino también por el último símil poético, evocador del mundo americano. Nervo no quiere cultivar la forma breve únicamente para congraciarse con el lector agobiado por el ritmo trepidante de la vida en el siglo Xx, sino que ante todo busca perdurar en su mente como un creador de belleza y un 
mentor que pueda servirle de guía y de refugio para hacerle más llevadero el camino. Así, el tono y la intención de Plenitud aparecen de lleno en este ensayo, publicado un año antes que el libro, cuya recepción va a acarrear un elemento suplementario que dificulta un poco más su clasificación genérica.

La Recepción de Plenitud

Los criterios editoriales cuando Nervo publicó sus últimos libros admitían textos completamente diferentes entre sí desde el punto de vista genérico, agrupados en una categoría única. Además, tomando en cuenta la enorme popularidad del poeta en el momento de su muerte, estas tiradas "de todo un poco", se multiplicaron para corresponder a la demanda de los lectores. Es así como encontramos un librito publicado en Montevideo en 1919, cuyo título Soledad se ve acompañado del subtítulo "Cuentos", con un contenido que es una recopilación de escritos heterogéneos. Entre los seis textos seleccionados, uno solo es un verdadero relato pues los otros "cuentos" son ensayos filosóficos, crónicas, aforismos dispersos y cuatro capítulos de Plenitud. ¡En la obra de Nervo no se respetan criterios genéricos de ninguna índole!

Estos criterios imprecisos podrían explicar por qué en el libro de Louis G. Lamothe, Hábleme del modernista mexicano Amado Nervo (1962), éste no vacila en ubicar Plenitud entre sus novelas, mezclando sus propias observaciones con nombres de capítulos de la obra, para presentarla como una novela sentimental y edificante, tan de moda en el siglo anterior:

PLENITUD (1918): El azteca posee un gran temperamento de novelista. Imagina con una inagotable fecundidad, pinta los paisajes con una justeza de rasgo y conduce su narración con una perfecta holgura. Así se granjea la simpatía de sus lectores por su idealismo. Cree en el amor y en la bondad de la mujer y hace una alabanza del amor en general.

"Dentro de ti está el secreto... Busca dentro de ti la solución de todos los problemas..." "No pienses: sufriré, me engañarán, dudaré... Siempre que haya un hueco en tu vida llénalo de amor, sin reparar si eres adolescente, joven o viejo" (Lamothe 1962: 57-58). 
Pero no nos detengamos en este caso extremo de clasificación genérica extravagante, y veamos cuál fue su acogida entre sus contemporáneos. Se desprenden dos actitudes mayores: el rechazo de la nueva modalidad de escritura y de su contenido eminentemente optimista, que expresa una tendencia, con resabios de dogmatismo, a predicar el amor hacia Dios y hacia los hombres para hallar la felicidad; o la adhesión incondicional de sus lectores, que adoptan los preceptos nervianos y tienden a considerarlo como un guía espiritual. La primera actitud se encuentra sobre todo entre los intelectuales, y la segunda más bien entre los admiradores anónimos. Las dos anuncian el porvenir que tendrá la obra de Nervo en las generaciones posteriores, y no solamente en las de sus compatriotas.

En su libro de 1919, Poetas y prosistas del novecientos, el intelectual español Rafael Cansinos Assens vapulea duramente el recién publicado libro del poeta mexicano:

Mas he aquí que en este último libro, Plenitud, da un adiós severo a la poesía, renuncia al traje gayo de los trovadores y se viste el hábito obscuro, que es toda la elegancia del claustro. ¡Pobre Amado Nervo! Le hemos perdido, le hemos perdido definitivamente (1919: 36-37).

Plenitud (1918) es un libro creyente y optimista, libro de fervor koránico, que sería admirable si su autor no hubiese rebasado el límite de los limbos espirituales, de la pura y vaga disposición religiosa que en Lamartine y en Renan se confunde con la disposición poética de que hablaba Schiller, para componer un manual de optimismo práctico que le emparenta turbiamente con la literatura para exploradores (42-43).

La irritación del crítico español es muy grande, a pesar de haberse mostrado elogioso en la primera parte de su ensayo, cuando comentó la poesía anterior al libro incriminado. Años más tarde, Luis Ignacio Helguera, en su Antología del poema en prosa mexicano, expresa las mismas reticencias a propósito de la escritura de Nervo en Plenitud, pero desplaza el problema hacia el de la clasificación genérica, en la medida en que debe justificar la inclusión de unos textos dentro de su selección:

Nervo conoció el poema en prosa, como lo prueba su referencia a "El extranjero" que ama las nubes y abre Le Spleen de Paris de Baudelaire, en la sexta prosa de Ellos, titulada "Las nubes", y ensayó algo semejan- 
te, en el tono y la intención de la exhortación espiritual, dentro de su ideal franciscano, agudizado con el tiempo, de desnudar la escritura hasta la sencillez, para conmover el fondo humilde del lector y probarle que la poesía anida incluso en lo más llano y pobre, la prosa. [...] Sin duda lo consigue, por ejemplo, en su breviario Plenitud (1918), sólo que a quien no espera de la literatura consuelo sino literatura, Nervo no lo convence. Su pretensión de ahondamiento filosófico — - socrático, estoico, cristiano- acaba casi siempre, por lo demás, en la superficialidad, la ingenuidad intelectual o el sofisma más burdo, como cuando invita a la despreocupación de los grandes enigmas metafísicos o al dogmatismo del que tiene que creer para no sufrir.

Desde el punto de vista literario, el casticismo de su lenguaje no equivale siempre a la sobriedad de estilo y expresión que buscaba, y la simplicidad mistica degenera a veces en la simpleza llana.

El Nervo de las prosas de Plenitud puso la literatura al servicio de la tediosa varita pedagógica y moralizante, y las metáforas y los motivos poéticos son meros instrumentos de la exhortación. Con todo y más allá del interés histórico, importan sus composiciones por lo escueto de la expresión y el sentido ritmico de la prosa9 (1993: 21-22. Cursivas mías).

En esta presentación de la prosa de Plenitud se ve muy claramente el apuro del editor de la antología. Echa mano del conocimiento del texto de Baudelaire para demostrar que Nervo conocía el género literario, pero niega la "literalidad" de los textos, ya que, aún los procedimientos poéticos, como la metáfora, "son meros instrumentos de exhortación" y "la simplicidad mística degenera a veces en la simpleza llana”. En efecto, la prosa es rítmica, pero, ¿será esto suficiente para transformar el texto corto en poema en prosa? Muy hábilmente escogerá un texto donde abunda el lenguaje metafórico y cuya construcción antitética permite clasificarlo en dicho género, pues pocos de los textos poseen esas características.

El éxito popular de Plenitud se sitúa en el otro extremo de la recepción, pues el libro tuvo muy buena acogida entre los lectores de

\footnotetext{
${ }^{9}$ Es interesante observar en las notas a pie de página que acompañan estos juicios sobre Nervo, otras opiniones muy negativas como la de Carlos Monsiváis: "su misticismo para modistas y su portentosa cursilería"; o la de Octavio Paz: "el traje de simbolista — que le iba bien— es sustituido por el gabán del pensador religioso. La poesía perdió con el cambio, sin que ganara la religión o la moral”.
} 
Nervo, debido en gran parte a la fama que la poesía le había proporcionado a su autor en las primeras décadas del siglo Xx. En efecto, era el resultado directo de la gran moda de los recitales poéticos en América Latina, fenómeno extraordinario durante el período modernista y hasta bien entrada la segunda mitad del siglo xx. Los mismos autores (Darío, Chocano, Nervo, entre otros) llenaban salones y paraninfos con un público ávido de oírlos declamar sus versos. Carlos Monsiváis lo resume muy bien en un capítulo consagrado a la poesía y a la cultura populares:

A la especie de los declamadores que se difunde con brío a fines del siglo xIx, la consolidan el culto a la brillantez verbal y el recuerdo de las galas de la oratoria sacra, aquellos sermones que son dramas teológicos comprimidos, guías de turistas del cielo y el infierno. Por virtud de la declamación, la poesía deja de ser íntima y se vuelve pública, no el convenio entre un autor y un lector, sino entre una audiencia y un actor, sacerdote del idioma, taumaturgo que resuscita las palabras asesinadas por las voces monocordes (Monsiváis 2001: 129).

Sobre todo, esto era muy cierto en el caso de Nervo, ya que éste representaba el mayor poeta modernista después de la muerte de Rubén Darío en 1916, y su mensaje franciscano y sentimental, expresado en versos sonoros y fáciles de memorizar, correspondía perfectamente a lo que anhelaban sus lectores y sus múltiples declamadores. Plenitud llega pues cuando el poeta está en la cumbre de su fama y su mensaje es muy del agrado de las muchedumbres. Como lo señala Monsiváis en el estudio mencionado:

A los frecuentadores (más que lectores) de los modernistas, los poemas resultan emociones prestigiosas. Estos feligreses (término adecuado) no oyen o leen poemas, sino fragmentos de la totalidad verbal que los incorpora a la profundidad del sentimiento (131).

Por lo demás, cuando Nervo regresa a México en julio de 1918, tras una larga ausencia, su llegada se celebra en todos los periódicos importantes de la capital, donde llega precedido de una fama de hombre bondadoso y cultivador del misticismo, fama que libros tales como Serenidad, Elevación y el recién publicado Plenitud, habían venido estableciendo. Como ejemplo, veamos un extracto de un artículo 
publicado en El Nacional del 7 de julio de 1918, que se opone totalmente a la opinión de Cansinos Assens, antes citada:

Nervo es como debía ser y su obra es toda él. Así, su discutido misticismo no es de primitivo cristiano, ni de eremita, ni el sabio de un doctor de la iglesia, ni el complicado de un escolástico, ni el de un inquisidor, ni el intransigente de un conquistador, ni el misericordioso, resignado, melancólico y gris de las familias tradicionales de los pueblos de provincia. El misticismo de Amado Nervo es su misticismo, sin éxtasis, sin torturantes meditaciones, sin ritos, sin prédicas, sin dogmatismos; sólo con Dios, con los hombres y con las cosas buenas, bellas y sencillas (Villalpando 1918).

Esta interesante muestra de la prosa periodística de aquella época es a la vez representativa de un tipo de escritura que se destinaba al lector medio (El Nacional es un diario de la tarde de gran tirada), y de la imagen que el poeta diplomático había adquirido entre sus conciudadanos. De manera que al año siguiente, cuando Nervo falleció en Montevideo, otro poeta mexicano, Miguel Othón Robledo, en su artículo "El hombre y el símbolo", ¡lo canoniza definitivamente! Escribe: "El hombre ha muerto. Sólo queda el símbolo, el símbolo de una deidad perenne, la ilusión, a nombre de la cual te ofrecemos, oh San Amado Nervo, la más rica de nuestras joyas: la del amor" (Othón Robledo 1919).

Ese aspecto de la recepción de su último libro, que aparentemente nos aleja de la dificultad de su clasificación genérica, no es así, pues nos ha permitido determinar que la imagen pública de Nervo era la de un poeta místico y la de un guía espiritual. Entonces, cabe preguntarse aquí si Plenitud es el libro de un poeta en prosa o el de un pensador que se expresa por medio de aforismos ataviados de procedimientos poéticos. Sobre todo, que el descubrimiento reciente de otros textos contemporáneos de la obra, y muy similares en la forma y el contenido, permitirán darle un nuevo enfoque al problema considerado.

PoEMAS EN PROSA O PROSAS EN POEMA: EL TEXTO CIFRADO

Cuando se hojea la edición original de Plenitud, nos damos cuenta de que este librito está compuesto de sesenta textos cortos, numerados 
con romanos y con un título distinto para cada uno. Por lo tanto, esta composición incita de inmediato a una lectura fragmentaria, ya que cada texto es autónomo con relación al conjunto, aunque el sitio que ocupa en el libro le fuera asignado por su autor. Algunos títulos darán una idea de su contenido general: IV. "Enciende tu lámpara"; XXIX. "No disminuyas la libertad de los otros"; XII. "La dulce tiranía"; XLIII. "No es que huyan los muertos: se fueron antes"; XLVII. "Dios padece en ellos"; LI. "Tu cuerpo", etcétera.

Observamos de inmediato que su tono es sencillo, parecido al de una conversación íntima durante la cual dos interlocutores charlan tranquilamente acerca de asuntos filosóficos, metafísicos o religiosos. Un narrador personal se dirige a un narratario, en este caso el lector, exhortándole a conocerse a sí mismo, a actuar con generosidad hacia los demás y a reflexionar sobre los grandes enigmas de la humanidad, como la muerte, el sentido oculto de la vida o la existencia de Dios, para así poder alcanzar un sentimiento de plenitud que lo colmará de alegría y felicidad.

Esta forma dialogada, herencia de la tradición griega y de algunas otras, tuvo un gran auge en la cultura europea posterior, e inserta la obra nerviana en la literatura didáctica, que expresa a la vez preceptos para comportarse mejor con sus semejantes y desarrolla temas de meditación para responder a las interrogaciones metafísicas del ser humano. Por lo demás, Nervo nos indica en un poema de 1917 cuáles eran sus lecturas preferidas en esa época, después de haber padecido el inmenso dolor de perder a la mujer amada y de vivir un amor no correspondido:

\section{LOS MANANTIALES}

Lee los libros esenciales, bebe leche de leonas; gusta el vino de los fuertes: tu Platón y tu Plotino, tu Pitágoras, tu Biblia, tus indos inmemoriales: Epicteto, Marco Aurelio... iTodo el frescor cristalino que nos brindan los eternos manantiales!

Diciembre, 21 de 1917 (OCAN II: 1797).

Este corto poema nos permite, hasta cierto punto, comprender sus intenciones y el estado de ánimo del poeta cuando redactó Plenitud. 
Sin duda buscaba integrar su libro dentro de la corriente del pensamiento occidental que encuentra sus orígenes en la Biblia y en los filósofos griegos, entroncándolo con la doctrina estoica y los misterios pitagóricos, y dando un rodeo por las filosofías orientales, muy de moda en la Europa finisecular. Nervo necesitaba frecuentar aquellos autores que aconsejaban la resignación, la conformidad con los golpes del destino y la creencia en una vida más allá de la muerte (llegando hasta la metempsicosis con las filosofías orientales), para alcanzar la serenidad y la paz interior. Lo que explica por qué el hilo conductor de la obra es un indestructible optimismo. Optimismo a propósito de los designios de Dios, de la naturaleza humana y de la belleza del mundo. El epígrafe de San Pablo (;Estad siempre gozosos!), cobra todo su sentido y el último texto de Plenitud, "Alégrate", desarrolla la misma idea con frases que connotan una eufórica alegría de vivir:

Alégrate si amas, porque eres más semejante a Dios que los otros. Alégrate si eres amado, porque hay en esto una predestinación maravillosa.

Alégrate si eres pequeño; alégrate si eres grande; alégrate si tienes salud; alégrate si la has perdido; alégrate si eres rico; si eres pobre, alégrate; alégrate si te aman; si amas, alégrate; alégrate siempre, siempre, siempre.

(OCAN II: 1059).

Este optimismo rotundo no alcanzaba a convencer a todo el mundo, como en el caso de Cansinos Assens, que escribía en el ensayo antes mencionado:

El poeta ha profesado en una Orden religiosa, si no es que se ha afiliado a una de esas Órdenes laicas que ahora disputan a las cogullas la misión de evangelizar a la Humanidad, a la orden quizás de los teósofos de Mme. Blavatsky. Así habrá de ser, más verosímilmente, a juzgar por el tono de militante optimismo en que está escrito este libro (42-43).

Esta observación incita a estudiar el texto más detenidamente, y lo primero que llama la atención en la portada de la edición original es el ex libris que reproduce el monograma grabado en el anillo del poeta. En efecto, la A mayúscula presenta un grafismo que recuerda curiosamente el compás, símbolo masónico muy conocido, y la N, puesta al 
revés, bien podría equipararse a una escuadra, la otra figura que generalmente lo acompaña. Esta hipótesis parece confirmarse en los textos cuando, en el que inicia el libro, se encuentran expresiones sacadas del lenguaje de la masonería, como la que designa a Dios como "Gran arquitecto del Universo", o los nombres de herramientas de albañilería:

\section{DENTRO DE TI ESTÁ EL SECRETO}

Busca dentro de ti la solución de todos los problemas, hasta de aquellos que creas más exteriores y materiales.

Dentro de ti está siempre el secreto; dentro de ti están todos los secretos.

Aun para abrirte camino en la selva virgen, aun para levantar un muro, aun para tender un puente, has de buscar antes en ti, el secreto.

Dentro de ti hay tendidos ya todos los puentes.

Están cortadas dentro de ti las malezas y lianas que cierran los caminos.

Todas las arquitecturas están ya levantadas dentro de ti.

Pregunta al arquitecto escondido: él te dará sus fórmulas.

Antes de ir a buscar el hacha de más filo, la piqueta más dura, la pala más resistente, entra en tu interior y pregunta...

Y sabrás lo esencial de todos los problemas, y se te enseñará la mejor de todas las fórmulas y se te dará la más sólida de todas las herramientas.

Y acertarás constantemente, pues que dentro de ti llevas la luz misteriosa de todos los secretos.

(OCAN II: 1037. Cursivas mías.)

$\mathrm{Al}$ analizar la escritura de este primer texto, se observan características formales que se relacionan a la vez con aspectos retóricos y con la construcción del texto. Los párrafos son muy cortos, con tiempos verbales ya sea en presente de indicativo ya sea en futuro, y una mayoría de imperativos para acentuar su carácter oral y conferirle un tono exhortativo, muy cercano al de los ejercicios espirituales, compuestos por lo general de pensamientos expresados con frases breves, imperativas, que pretenden ser a la vez receptáculo para la meditación e incitación para la práctica. Para atraer al lector, el narrador utiliza estructuras iterativas (dentro de ti) y construcciones de ritmo ternario (para abrirte camino..., para levantar un muro..., para tender un puente...), que desarrollará, en este caso, empleando los participios pasados de los infinitivos. Utiliza 
luego el mismo procedimiento, pero esta vez por medio de la enumeración de las tres herramientas, que corresponden a los tres verbos citados, con una construcción sintáctica paralela, compuesta de un sustantivo / un adverbio / un adjetivo: el hacha de más filo, la piqueta más dura, la pala más resistente. La palabra "secreto", colocada estratégicamente al final del título, está repetida cuatro veces en el texto, sobre todo en la segunda oración, donde se sirve de un poliptoton, muy parecido a la construcción del superlativo hebreo, y cuya forma plural es la última palabra del texto.

Al estudiar las imágenes, además del simbolismo masónico, observamos que se componen de una serie de metáforas que representan las dificultades del hombre durante su existencia, y que estas imágenes forman una red semántica a través del uso de un vocabulario que remite a la construcción y a la arquitectura. Eso sí, si bien se trata de un texto donde aparecen recursos poéticos y retóricos, en ningún momento tendemos a asimilarlo a un poema en prosa, pues si dicha prosa es indudablemente rítmica, el texto no genera tensión alguna en la medida en que ninguna construcción antitética lo sostiene, ningún conflicto aparece entre el narrador y el mundo que lo rodea y su tono didáctico no despierta ninguna emoción poética en el lector.

Estas construcciones sintácticas y los demás procedimientos aparecen en la casi totalidad de los textos, con una serie de temas recurrentes: el secreto, el amor hacia los demás y hacia Dios, dar sin esperar algo en retorno, conformarse con lo que se posee, tener fe en Dios y en el hombre, aceptar sin quejarse lo que ofrece la vida, reflexionar sobre la naturaleza divina, creer en la vida después de la muerte, respetar su cuerpo, y hacer el bien a los que nos rodean para alcanzar la serenidad y la alegría. Temas éstos que traducen un objetivo pedagógico y una voluntad de difundir un sistema ideológico, presente a lo largo de todo el libro.

De manera que, volviendo a la crítica de Cansinos Assens y al descubrimiento del simbolismo masónico en el texto liminar de la obra, sorprende sobremanera hasta qué punto el vocabulario del ocultamiento y del misterio se hallan presentes, como si fuese necesario descifrar el mensaje escondido para alcanzar la verdad: en el texto VI se encuentra la expresión "La LEY escondida" (OCAN II: 1039) y en el último párrafo del texto IX, "Aprende a conocer el hambre del que te habla... en el concepto de que, fuera del hambre de pan, todas se es- 
conden. Cuanto más inmensas, más escondidas..."(OCAN II: 1040); el texto siguiente se titula "Almas recatadas" y aconseja dirigirse hacia los demás y no atrincherarse en el secreto del alma, exhortando al lector a revelar sus misterios para compartirlos con sus semejantes. ${ }^{10}$ Mientras que otros textos, más adelante, evocan el motivo de las máscaras (que sirven para escondernos de los demás y, a veces, de nosostros mismos), los enigmas y los misterios del universo (cuya respuesta encontraremos después de la muerte) o la llave que cierra la puerta del castillo donde viven los fantasmas, nuestros miedos ocultos, y que debemos conservar cuidadosamente cerrado para no dejarnos invadir por la desesperación.

Estos elementos sugieren una posible codificación del texto de Nervo. Se ha descubierto parte de su misterio al analizar el simbolismo masónico, pero prosiguiendo por la misma vía, nos topamos en su obra con sorprendentes ecos de la doctrina de un extraño personaje, muy amigo de Nervo y que, al parecer, tuvo una gran influencia sobre el hombre y su ideología: Arnold Krumm-Heller (1876-1949), más conocido entre los medios del esoterismo como Huiracocha. ${ }^{11}$

En su biografía, Krumm-Heller aparece como un personaje extravagante, nacido en Alemania, aunque gran parte de su familia había emigrado de Europa para instalarse en México a comienzos del siglo XIX. Esto explica por qué siempre tuvo relaciones estrechas y privilegiadas con ese país, llegando a poseer la nacionalidad mexicana y a convertirse en su representante diplomático ante la Unión Nacional de Weimar en 1919. Estudió medicina en su juventud con los indios de América del Sur y, alrededor de 1897, viajó a México y empezó a interesarse por la política. Fue nombrado profesor de alemán y de literatura, y consiguió ocupar un puesto importante como médico principal en el estado mayor del presidente Francisco I. Madero (18731913). Más tarde, el presidente Venustiano Carranza (1859-1920) lo nombró director general de las Escuelas especiales locales. Después del asesinato del político mexicano en 1920, Krumm-Heller regresó a Alemania donde compró una imprenta. Fue entonces cuando comenzó una carrera de periodista y de escritor de novelas sin gran valor literario y, en 1921, publicó el primer ejemplar de su revista Der Rosen-

\footnotetext{
${ }^{10}$ Esto remite a la dedicatoria del libro: "Esta es mi riqueza. Toda para ti."

${ }^{11}$ Como todo lo que se refiere a este personaje no es de fácil acceso, sólo pude encontrar información en portales de Internet. Sus obras están publicadas por la Editorial Kier de Buenos Aires.
} 
kreuze (El Rosa-Cruz), corredactada con Théodor Reuss, en la cual ambos se autoproclaman Rosacrucianos. El médico alemán continuó ejerciendo sus actividades esotéricas, fundando logias y viajando a los distintos países de Europa y de América. Murió en 1949 en Alemania, donde había manifestado su simpatía por el régimen nazi de Hitler durante los años del auge del Tercer Reich, y el menor de sus hijos, Parsifal, continuará la difusión de la doctrina de su padre.

Este extraño doctor alemán conoció sin duda al joven periodista Nervo antes de que éste efectuara su primer viaje a París, en los últimos años del siglo XIx. En efecto, Krumm-Heller ejercía la medicina que había aprendido en Suramérica y había abierto un consultorio en la capital mexicana. En todo caso, una sólida amistad se desarrolló entre los dos hombres, como lo señala la biografía del alemán en la Enciclopedia Espasa: "Fue íntimo amigo de Amado Nervo, cuyas más bellas páginas tradujo al alemán." $12 \mathrm{El}$ caso es que el curioso médico, que comenzaba a trepar en las altas esferas del gobierno mexicano, era ya un gran adepto del esoterismo y, desde 1897, se había convertido en miembro de la Sociedad Teosófica de París, frecuentando luego durante diez años los círculos esotéricos y ocultistas de la capital francesa, donde conoció a gentes como Gérard Encausse (Papus), Eliphas Levi, Stanislas de Guaîta, Théodor Reuss y otros representantes de la Iglesia Gnóstica. También fue iniciado en diferentes logias masónicas, donde accedió a grados elevados, adquiriendo el título de comendador de la Fraternitas Rosicruciana Antiqua para todos los países de habla hispana.

Cuando los dos hombres se conocieron, el alemán atravesaba por una crisis importante, sobrevenida después de la muerte de su madre en Alemania, que lo condujo hacia el espiritismo de Allan Kardec. Pero, rápidamente, se alejará de estas prácticas para dirigirse hacia las indagaciones esotéricas descritas en el párrafo precedente. Es muy posible que durante los primeros años del siglo $\mathrm{XX}$, las trayectorias de los dos hombres siguieron encontrándose en Europa, y sobre todo en París, ya que ambos viajaban regularmente a Francia. El interés que presenta esta amistad en el marco de nuestro trabajo reside en la repercusión que las ideas y sobre todo el estilo de Krumm-Heller tuvieron sobre los escritos de Nervo. Esta influencia de la retórica utilizada

12 Consultar : www.telepolis.com/agaigcu/biografia HUIRACOCHA.htm 
en los medios esotéricos va a llegar hasta a falsear la escritura del poeta, contaminando su expresión poética con un discurso donde se mezclan proselitismo y objetivo didáctico. Por lo tanto, llama de inmediato la atención la similitud de procedimientos retóricos y de tono al comparar dos textos, uno escrito por el alemán y el otro sacado de Plenitud:

\section{EL MAESTRO HABLÓ...Y NOSOTROS ESCUCHAMOS EXORDIO}

Krumm-Heller

No hables a todos de las cosas bellas y trascendentes...

En el decir bíblico, sería tanto como arrojar margaritas a los cerdos. ${ }^{13}$ Pero $[\ldots]$

En todos, sobre la copa de todos, dulce o amarga, de frivolidad o de ignorancia, escancia tu Vino y con él, el pétalo de rosa de ensueño [...]

Para los que padecen de eterna inquietud, de supremas ansias. Para los que sienten la augusta zozobra que produce lo no realizado y viven esperando $[\ldots]$ esperando [...] el día luminoso que ha de venir [...] Para esos, será el bálsamo, el néctar, la magna palabra que abre todas las rutas y alumbra todos los senderos.

Para los que no tienen hambre y sed de vida, para los frívolos. Para los que van con paso ligero por la senda y no advierten la floresta, ni el ave que canta, ni el dulce murmurar del arroyo, ni la vieja fuente grata de sonoro cristal — comodijo el Poeta [...] — Para esos, no será el bálsamo, ni la magna obra, pero [...] sibeben de este vino sagrado, más allá del tiempo, florecerá su sabor y llenarán su copa. [...]

\section{EL SIGNO}

No hables a todos de las cosas bellas y esenciales.

No arrojes margaritas a los cerdos.

Desciende al nivel de tu interlocutor, para no humillarle o desorientarle. Sé frivolo con los frívolos...: pero de vez en cuando, como sin querer, como sin pensarlo, deja caer en su copa, sobre la espuma de su frivolidad, el pétalo de rosa del Ensueño.

(OCAN II: 1038. Cursivas mías.)

\footnotetext{
13 Arnold Krumm-Heller, "arrojar margaritas a los cerdos", "no realizado”, “no”, “sonoro cristal” y "uno”. En los otros casos, las cursivas son mías.
} 
Al leerlos uno después del otro es impresionante la similitud que presentan entre sí. Por desgracia, actualmente es imposible atribuirle una fecha al texto de Krumm-Heller, pues la revista rosacrucista que lo publica no la suministra, pero parece innegable que un texto sirvió de modelo al otro. Por otra parte, además de los probables encuentros de los dos amigos en Europa, no hay que olvidar que Krumm-Heller formaba parte de los personajes cercanos al presidente Carranza, que vivía en México donde desempeñaba un papel importante en la política local y que, en 1918, Nervo había regresado a su país para encontrar un nuevo cargo diplomático, ya que su mandato en España había terminado. Seguramente, en ese momento, intereses a la vez políticos y amistosos debían reunir a los dos hombres.

Ahora bien, el texto $\mathrm{V}$ de Plenitud es más explícito en cuanto a su contenido simbólico pues evoca un signo que vendría a ser el santo y seña de las sociedades secretas para que sus miembros pudieran identificarse entre sí. En el texto del alemán, las imágenes poéticas son más numerosas, pero el objetivo de difundir un discurso que permita al hombre alcanzar la libertad es idéntico. Entonces, este nuevo enfoque permite considerar Plenitud ya no como una colección de poemas en prosa sino como un breviario para los futuros discípulos, cuya meta es ayudarlos a penetrar los misterios esotéricos con una ideología rosacruz, que en ningún momento se opone a la religión, como lo expresa KrummHeller en su texto La finalidad Rosa Cruz: "A la Fraternidad Rosa Cruz pueden pertenecer personas que tengan cualquier credo religioso, y también los que no tengan ninguno, pero siempre aceptando la existencia de la Divinidad Creadora, de la que todos formamos parte". ${ }^{14}$ Esto es sumamente importante, ya que el Nervo místico y cristiano puede convivir perfectamente con los ideales rosacruces, pues la adhesión a ese tipo de fraternidad conlleva una búsqueda espiritual y un inmenso deseo de conocimiento. Un artículo de un adepto de la orden, firmado con el seudónimo F. L. Zerion, describe estos objetivos, cita al poeta mexicano sin ninguna ambigüedad y concluye exhortando al discípulo a elevar su espíritu, por medio de un lenguaje metafórico:

Los grandes Rosacruces han sido siempre eclécticos: ser ecléctico según la filología del término, es tomar lo mejor, seleccionándolo, con el fin

${ }^{14}$ Arnold Krumm-Heller, www.ordenkabalistarosacruz.50megs.com/Pagó12.htm 
de ir marchando en línea ascendente de lo bueno a lo mejor, y de lo mejor a lo óptimo, tomando naturalmente de las más puras fuentes de la sabiduría tradicional de los Rosacruces, cuyo origen se pierde en la noche de los tiempos.

El alma del hombre, como dijo el insigne rosacruz Amado Nervo, "Es una copa que solamente se llena con la eternidad." ${ }^{5}$ [...]

[...] así debe ser el alma templada del que aspira a las grandes realizaciones de la conciencia; de todo tiene experiencia, pero a nada se liga, todo lo supera, todo lo ennoblece y todo lo diviniza en su silente alquimia, hasta ir alcanzando la luz y el calor del único verdadero maestro y guía que es la íntima consciencia... "Cristo en nosotros." 16

En el libro de Nervo es evidente que el mensaje rosacruz es más difuso, pues tenía que tener cuidado de no herir las convicciones y las opiniones de sus numerosos lectores. Lanzarse a una literatura de propaganda esotérica habría significado destruir su imagen de poeta franciscano y místico, y la de un hombre inconsolable después de la muerte de su amada. La reacción violenta de Cansinos Assens, que no andaba tan errado, es una muestra de la mala acogida que podría haber tenido el libro si su autor se hubiese mostrado más explícito. De manera que el símbolo de la rosa, omnipresente en Krumm-Heller, se torna muy discreto en Nervo, ya que, fuera de la alusión a "el pétalo de rosa del Ensueño" que notamos en el texto V de Plenitud, sólo se encuentran otras tres alusiones furtivas a la flor simbólica: XLVII. "Y tus dichas florecerán como rosas plenas después de una estación entera de rosas"; LV. "[Los dolores pasados] que hicieron florecer en nuestras almas esa divina y encendida rosa de la piedad"; y XXXIX. "Mira la rosa cómo sin dolor, desabrocha su justillo, florece y muere". Sin embargo, estas tres alusiones con el verbo "florecer" son muy importantes pues reproducen la divisa de la Rosa Cruz tal y como la presenta

15 Esta cita está sacada de la poesía "La sed" de El estanque de los lotos. En la edición de Alfonso Reyes (vol. XVIII), éste señala: esta poesía apareció antes con el título "El vaso". Y en la edición de Aguilar, al final del texto aparece la fecha "26 de marzo de 1918", año de la publicación de Plenitud. He aquí la última estrofa del poema: "Displicente marchas del orto al ocaso / no hay fuente que pueda saciar tu ansiedad / por mucho que bebas... ¡El alma es un vaso / que sólo se llena con eternidad! (OCAN II: 1801).

16 F.L. Zerion, www.club.telepolis.com/agaigcu/rosacruzhermandaddelsaber.htm (Las cursivas son mías.) 
Krumm-Heller en "Así florecerán tus rosas" de Rosa esotérica: "Busca lo Esencial. [...] Tu Cruz se hará más llevadera y la Rosa le prestará su sagrado perfume. [...] Asi florecerán las Rosas sobre tu Cruz."17

El ejemplo precedente es una excelente ilustración de la contaminación entre dos modalidades de escritura, una esotérica y la otra poética. El objetivo de escribir poemas en prosa parece alejarse cada vez más de las intenciones del autor mexicano, a favor de esta nueva forma de expresión que conserva las imágenes poéticas, al mismo tiempo que esconde la doctrina de la fraternidad rosacruz. Por su parte, el ocultista alemán en un libro compuesto de textos cortos, Rosa esotérica, presenta en prosa rítmica las finalidades de la obra. Krumm-Heller se dirige a un narratario que se puede fácilmente asimilar al lector de Plenitud, pero se muestra mucho más explícito en lo que atañe al mensaje rosacruz:

\section{TU LIBRO}

Ten este Breviario Filosófico.

Por encima de la Filosofía de la Vida, más allá de cuanto sepas, sobre todos tus conocimientos, ten este Breviario Filosófico...

Escógelo entre muchos, silenciosamente...

Selecciónalo entre todos, calladamente...

Búscalo entre la multitud de los otros Libros, sin decir cuál prefieres... Él surgirá como si tuviera un alma y se vendrá a tus manos lleno de alborozo porque estaba hecho para ti. [... $]^{18}(13)$

Nervo, al contrario, salpicando ligeramente el texto con símbolos masónicos y rosacruces, y con un tono voluntariamente más neutro y de alcance más universal que el simple discurso esotérico, publica su libro sin temor de verse atacado por los adversarios del esoterismo y de las prácticas ocultistas. En cierta forma, crea un engaño para que sólo los verdaderos "iniciados" puedan descifrar su texto, pues esconde sus verdaderas fuentes para no revelar los misterios que constituían la base de ese tipo de sociedad secreta. Y, por otra parte, la codifica-

\footnotetext{
${ }^{17}$ www.fratreslucis.netfirms.com/Fra01.html. En este portal se pueden encontrar algunas obras de Krumm-Heller, y entre ellas, el texto completo de Rosa esotérica. Ver también la edición en Buenos Aires de editorial Kier, 1990.

18 Arnold Krumm-Heller, www.fratreslucis.netfirms.com/Fra01.html.
} 
ción de Plenitud se lleva también a cabo con la inserción de algunos capítulos que no contienen las mismas características de escritura. Así pues, en el libro de 1918 se encuentran algunos textos cuya construcción y utilización de procedimientos poéticos, parecen relacionarlo con otro género. Son justamente aquéllos que se han incluido en las antologías de los poemas en prosa, y que son los responsables de la tendencia en algunos críticos de clasificar la totalidad del libro como una colección de ese tipo de composiciones. Por lo demás, en la medida en que la retórica esotérica se apoya sobre un mundo de símbolos y de metáforas, estos escasos textos no desentonan en el conjunto del libro. $\mathrm{Al}$ contrario, aparecen como los más originales y los más personales desde el punto de vista de la creación literaria. Se trata de cinco textos entre los sesenta que componen la obra: XI. "Las máscaras"; XIV. "Los enigmas"; XXI. "Oro sobre acero"; XXII. "La llave" y XLII. "Los pasos".

En la Antología crítica de la prosa modernista hispanoamericana, publicada en Nueva York por J.O. Jiménez y Antonio R. de la Campa en 1976, se encuentran los tres primeros textos de Plenitud citados en el párrafo precedente, en la sección consagrada a los poemas en prosa de Nervo. En cambio, en la nueva versión de la antología fechada en 1998 y que J. O. Jiménez elabora con Carlos Javier Morales, no aparece mas que un solo texto del autor mexicano, "Las máscaras". Por su parte, Luis Ignacio Helguera en su Antología del poema en prosa en México (1993), escoge únicamente "Los pasos" de Plenitud; pues, "Como el molino" está sacado de De mi breviario intimo (OCAN. II: 1035-1036) y "7 de noviembre (1912)" es un corto fragmento de La amada inmóvil. Por fin, a estos cuatro textos del último libro de Nervo, se puede agregar "La llave" que, a mi parecer, tiene rasgos comunes con dicho género.

"Las máscaras" se sitúa al comienzo del libro:

\section{LAS MÁSCARAS}

Cada año pone en $t u$ faz una nueva máscara.

Éste, alegre; aquél, indiferente; el otro, triste; el venidero, acaso gesticulante y ridícula.

Cada año pone en tu faz una nueva máscara, y se va...

Pero tu yo impasible, cuya fisonomía sólo conocen los dioses, sabe que él no es la máscara: que él ni sonríe, ni llora, ni gesticula.

$\mathrm{Tu} y o$, al verse en el espejo a través de las ventanas cada vez menos luminosas de los ojos, se dice a sí mismo: 
"He aquí el antifaz nuevo que me ha puesto la vida."

...Y sigue pensando en otra cosa.

Muchas de tus máscaras han quedado para largo tiempo en las fotografías. Durarán más de lo que merecen. Pero ninguna ha sido en ningún momento la expresión exacta de tu yo.

Que esto te enseñe a buscar en los hombres la fisonomía interior, la fisonomía escondida. Alguna vez podrás decir: "aqui hubo un ángel y yo no lo sabia".

(OCAN II: 1040. Cursivas mías)

El motivo de la máscara que construye el texto, aparece aquí con toda su ambigüedad intrínseca: "revela los deseos más ocultos (nuestras identificaciones fantasmales) en el período del carnaval, descubriendo entonces nuestro rostro 'oscuro' más recóndito, pero también puede servir para ocultar el 'yo de luz' en nuestra apariencia cotidiana” (Cazevane 1996: 402). Así, Nervo continúa desarrollando la temática del misterio y la ocultación, utilizando el motivo de la máscara para incitar al narratario a practicar la divisa socrática "conócete a ti mismo”, para alcanzar finalmente el conocimiento de los demás.

La dualidad de la máscara se traduce en la escritura por medio de la oposición entre "máscara", palabra esdrújula con una vocal abierta repetida tres veces, y el monosílabo desmedrado "faz", con su vocal única. Aún cuando el sinónimo de "máscara", "antifaz" surja más adelante, siempre se percibe la oposición entre ambos objetos y cómo, a su vez, "tu faz", cubierta por la "máscara" se opone a "tu yo impasible". Un juego de enigmas se instaura también entre el lector y el texto cuando el narrador, en la segunda frase, deja planear una ambigüedad a través de los adjetivos invariables, "alegre, indiferente y triste", que pueden remitir tanto a "año" como a "máscara". Pero la máscara domina sólo en apariencia, pues retomando el pensamiento de Platón, el texto presenta un juego especular entre las apariencias engañosas y el yo profundo que permanece escondido mientras nos dejemos guiar por ellas. Las palabras "espejo, ventanas" y "fotografías", superficies lisas que sólo son capaces de restituir el reflejo de las cosas, no pueden reproducir más que las máscaras sucesivas, apariencias ilusorias y efímeras del yo. Hay que mirar bajo la máscara, como en algunos ritos iniciáticos, para descubrir los secretos y acceder a la verdad. Se encuentran una gran mayoría de tiempos verbales, en presente y en futuro, con unas breves apariciones del pretérito perfecto para actualizar las 
acciones pasadas. Hay muchos paralelismos sintácticos como en el segundo párrafo donde se hallan una serie de pronombres y de demostrativos acompañados de distintos atributos, entre los cuales el último, "gesticulante", recuerda el uso de las máscaras en el teatro, remitiendo implícitamente al "gran teatro del mundo". Un juego paronomástico surge entre "tu yo y cuya", que permite un leve deslizamiento, de "tu yo impasible" a un "tu ya imposible", restituyendo el paso inexorable del tiempo evocado en la primera frase del texto. Éste aparece, pues, construido con párrafos cortos y con estructuras iterativas, en una prosa rítmica y cadenciosa. La presencia del narratario que realiza una trayectoria virtual por medio de las palabras del narrador que lo conduce del yo, "máscara efímera", que cubre el rostro superficial, hasta el yo, "ser de luz", manifestación de la naturaleza divina del hombre, le confiere unidad y circularidad.

De hecho, el pequeño texto de Plenitud adquiere un carácter poético sobre todo en la primera parte, pero los dos últimos párrafos recuperan el tono de los ejercicios espirituales con los giros exhortativos y la imagen del ángel que contrasta con las metáforas iniciales. Parece una torpeza utilizar en un mismo texto breve un sustrato de filosofía griega y una estampa cristiana popular, a menos que la intención didáctica sea más importante que la poética. Sin embargo, tampoco se puede excluir una interpretación más conforme al contenido esotérico del libro, en el cual el ángel desempeña un papel de intermediario entre Dios y los hombres, y su aparición al final del recorrido iniciático del neófito representaría el "yo de luz" del simbolismo de la máscara. La forma podría confirmar dicha ambigüedad, pues los dos últimos párrafos son más largos y los paralelismos iniciales desaparecen por completo. En todo caso, según la interpretación, la aparición del mensajero celeste podría ser el punto de tensión del texto, ya que el iniciado recorre el camino que lleva de la oscuridad (la máscara), hasta la luz del conocimiento y del amor de Dios: "aquí hubo un ángel y yo no lo sabía”. O, al contrario, si se considera al ángel como un cromo que reproduce al conocido Ángel de la Guarda de la cultura popular religiosa, el texto cae al final en lo que Monsiváis llama "misticismo para modistas". ${ }^{19}$

\footnotetext{
${ }^{19}$ Ver nota 9.
} 
El texto XIV, "Los enigmas", también hace referencia al tema del secreto y del misterio, pero esta vez es la muerte, misterio supremo, quien dará las respuestas.

José Olivio Jiménez en su primera antología de la prosa modernista incluye un texto de Plenitud, "Oro sobre acero", que es probablemente uno de los más hermosos del libro. Juega con la oposición entre la fuerza del acero y la belleza del oro, cuando éste cubre con su brillo la resistencia del metal precioso, embelleciéndolo con motivos geométricos o naturales; como, cuando la voluntad más recia se presenta ornada con la cortesía y la suavidad para triunfar sin agresividad ni violencia:

\section{ORO SOBRE ACERO}

Oro sobre acero - Eibar y Toledo- han de ser tus amores.

Oro sobre acero tu voluntad.

Oro sobre acero tus actos.

Sobre el acero del mejor temple de tus resoluciones brillará el oro puro y aristocrático de tu cortesía.

Sobre el acero de tus pensamientos ha de lucir el arabesco de oro de la forma pura y ágil.

Tu don de gentes será capa de oro fino que ha de recubrir el acero de tus propósitos.

Serán tus sonrisas como minúsculas estrellas áureas incrustadas en el acero de tus intentos.

Tu amor, firme, tendrá el oro de tu ternura sobre su acero imperioso.

Sobre el acero de tu aspereza, la placidez con que sabes aguardar será también oro. El áncora de la diosa estará damasquinada por ese oro de tu apacibilidad expectante.

Oro y acero — Eibar y Toledo — será tu Vida, serán tus propósitos, serán tus actos...

(OCAN II: 1044-1045. Cursivas mías.)

El texto evoca el damasquinado que se efectuaba en las ciudades de Toledo y de Eibar, en el país vasco, magnífico ejemplo de la artesanía árabe en la peninsula ibérica. Esta interpretación es evidente ya que las dos ciudades aparecen citadas en la primera frase, como también las palabras "arabesco" y "damasquinada". Arabescos que se hallan igualmente en la construcción del breve texto, donde verso y prosa se entrelazan armoniosamente como ambos metales en los trabajos 
de orfebrería. Las anáforas y las aliteraciones con la vibrante $r$, ya presente en el título, se prosiguen con la repetición de las palabras "oro y acero" a lo largo de las frases siguientes, pues cada una remite a uno de los valiosos objetos creados por la técnica del damasquinado. Así, después del ritmo ternario de las tres primeras frases, la cuarta alude a la famosa espada de Toledo "temple", fabricada con el mejor acero del mundo. Viene luego el objeto con enchape de oro "capa de oro fino", cuyo valor y belleza se ponen de realce con este procedimiento, para llegar al bibelot delicado con sus "minúsculas estrellas áureas", que podrían evocar una hermosa pitillera o la carátula de un relojito antiguo. El valor metafórico del texto va surgiendo, gracias a un movimiento pendular que lo recorre por entero, enlazando la descripción del trabajo de orfebrería con su significado moral. Hasta concluir con la imagen de la diosa de "áncora damasquinada", es decir Isis, que tenía una gran importancia en las doctrinas esotéricas finiseculares. ${ }^{20}$ Entonces la oposición antitética entre los dos metales, pero que se armonizan de manera notable en la obra de arte, expresa una tensión, para resolverla de inmediato en la creación artística, a saber el texto mismo.

Cabe recordar aquí, que tal vez este texto es el resultado de una circunstancia personal del poeta. Efectivamente, su descendiente, el señor Rafael Padilla Nervo, me confió que un anillo que usaba siempre el poeta estaba hecho de dos metales, el oro y el acero. ${ }^{21}$ Cuando se conoce la importancia que tenían los metales en las doctrinas esotéricas, y ante todo el oro, símbolo del conocimiento absoluto para los alquimistas, el texto y la joya de Nervo, poseían seguramente para él un gran significado oculto, designándolo como un "iniciado" frente a los demás adeptos.

"Los pasos" fue escogido por Luis Ignacio Helguera para ilustrar un poema en prosa de Nervo en su antología, antes citada. Se presenta como un texto ligero, con metáforas y comparaciones sacadas del mundo animal, para evocar el aspecto efímero de la felicidad, que cualquier cosa puede destruir y alejar para siempre:

20 "Papus" (1865-1916), que fue uno de los maestros de Krumm-Heller, fundó la revista Le voile d'Isis en París en 1890.

${ }^{21}$ Ver nota 3. 


\section{LOS PASOS}

Muchas veces, en los breves intervalos en que se apacigua tu tráfago interior, te acontece oír unos pasos : unos pasos furtivos a lo largo de tu puerta.

Como los de un amante que ronda la casa de la amada.

Son los pasos de la dicha.

Son los pasos de una dicha modesta, tímida, discreta que desearía entrar.

Hay muchas dichas así.

Son como novicias temerosas.

Son como corzas, como graciosas corzas blancas. Todo las amedrenta.

$\mathrm{Si}$ escuchas estos pasos, abre inmediatamente tu puerta de par en par.

Abre también tu rostro con la más acogedora de tus sonrisas... y aguarda.

Verás cómo entonces los pasos tímidos se acercan; verás cómo la pequeña dicha entra con los ojos bajos, ruborosa, sonriente, y te perfuma la casa y te encanta un día la vida, y se va... mas para volver.

Desgraciadamente, muy a menudo, tus descontentos, tus deseos, y aun alguna alegría efímera y soflamera, hacen tanto ruido, que la corza blanca se asusta, y los leves pasos se alejan para siempre jamás.

(OCAN II: 1052. Cursivas mías.)

Por primera vez entre los textos de Nervo estudiados se efectúa una construcción metafórica cuya figura central es un animal, "la corza", que posee un gran valor simbólico en las distintas civilizaciones, tanto occidentales como orientales. Es ante todo el principio femenino, mas con una dualidad fundamental, ya que puede representar el amor, la belleza y la juventud, o tomar un aspecto diabólico, como en la leyenda de Bécquer, "La corza blanca". 22 Hay también ecos muy precisos de un discurso amoroso, el Cantar de los Cantares, cuando la llegada silenciosa de la dicha se compara con la del amante que "ronda la casa de la amada" y cuando las metáforas sacadas del mundo animal remiten implícitamente a las metáforas bíblicas. De manera que el campo de los sentidos se evoca a través de la blancura de la "corza", de los perfumes y de los sonidos ahogados para proclamar una dicha sosegada y efímera.

\footnotetext{
${ }^{22}$ Es interesante recordar que Gustavo A. Bécquer es considerado como uno de los precursores del poema en prosa en España (Cernuda 1960: 123-137).
} 
El texto del romántico español suministra a Nervo una serie de elementos populares, ya que éste retoma la tradición del animal fabuloso de las leyendas tradicionales, cuya blancura evoca la pureza y destaca su aspecto maravilloso. Es un sueño inaccesible, a menudo personificado por la búsqueda incesante de un cazador que, embelesado por la belleza del animal, lo persigue inútilmente hasta que se topa con la muerte. Esta carrera de la corza pone de relieve su agilidad y sus pies diminutos, que van dejando unas huellas leves en la tierra. Por lo tanto, el texto de Nervo presenta el animal con una sinécdoque en hueco, en la medida en que los pasos son las huellas que los pequeños cascos van imprimiendo en el suelo, cascos que la representan totalmente, con su andar ligero y veloz: "pasos furtivos", y que se equiparan a "los del amante que ronda la casa de la amada". En la leyenda becqueriana, el narrador compara tres veces los piececitos de la hermosa Constanza (la joven que se transforma en corza por las noches) con los de "la corza blanca":

[...] lo que es más particular, entre el rastro de las reses las breves huellas de unos pies pequeñitos como la mitad de la palma de mi mano, sin ponderación alguna.

Al decir esto, el mozo, instintivamente, y al parecer buscando un punto de comparación, dirigió su vista hacia el pie de Constanza que asomaba por debajo del brial, calzado de un precioso chapín de tafilete amarillo [...] (Bécquer 1993: 237).

$\mathrm{Al}$ adoptar esta interpretación del texto de Nervo, la metáfora, "pasos de la dicha", suministra una posible clave, pues el narrador sigue desarrollando el motivo popular de la metamorfosis de la mujer en "corza blanca", por medio de los símiles "novicias temerosas" con sus hábitos blancos, miedosas "todo las amedrenta", aunque hayan perdido su forma humana. Por otra parte, la interpretación de una intertextualidad bíblica, mostraría que es más bien a través de la alquimia del lenguaje poético que se opera la transformación. Mientras que en las leyendas populares, la corza trata de huir del cazador, en el texto de Plenitud, ésta se acerca tímidamente como una joven ingenua, pues una vez que se ha echado mano del mecanismo de la transformación, "la dicha" se comporta a veces como un animal temeroso, a veces como una joven desposada. De manera que el texto concluye con la lección moral de rigor, cuando el narrador previene a su narratario del peligro de per- 
der la verdadera felicidad, dejándose cegar por las "falsas corzas" que acarrean al hombre a su ruina, como en la leyenda romántica:

Delante de sus compañeras, más ágil, más linda, más juguetona y alegre que todas, saltando, corriendo, parándose y tornando a correr, de modo que parecía no tocar el suelo con los pies, iba la corza blanca, cuyo extraño color destacaba como una fantástica luz sobre el oscuro fondo de los árboles (246).

Por el contrario, en el contexto amoroso del Cantar de los Cantares, la exaltación de la sensualidad está muy presente, la mujer no aparece en ningún momento como una seductora peligrosa y lo que amenaza el sentimiento amoroso y la dicha es la separación de los amantes.

El último texto de Plenitud que estudiaremos aquí, "La llave", nunca ha sido escogido para formar parte de las antologías del poema en prosa modernista. Pero lo hemos seleccionado por su contenido alegórico que parece emparentarlo con ese género:

\section{LA LLAVE}

¡Qué admirable es la llave de oro que cierra cuidadosamente la puerta del castillo donde viven los fantasmas!...

Si sabes usarla, si tienes cuidado de que esta puerta en determinados momentos no se abra, por más que desde adentro el tumulto de las triste$z a s$, de los temores, de las preocupaciones, de la pasión de ánimo, quiera forzarla, ¡cuánta será tu paz y cuán permanente tu alegría!

$\mathrm{Al}$ principio es muy difícil cerrar esta puerta: los fantasmas negros tiran de las hojas con toda su fuerza; logran mantenerlas entreabiertas, y se van colando por allí e invaden el campo de tu alma, y arrancan de él las santas flores de la alegría.

Pero la gimnasia vase haciendo cada vez más fácil y segura. Adquiérese una gran agilidad; sorprendes en seguida los movimientos astutos de la turba negra, y acabas por confinarla definitivamente en el castillo de la Pe$n a$, de las Imaginaciones dolorosas, de los Miedos sin razón, de las Angustias sin objeto...

Lo esencial es ser rápido en los movimientos. En cuanto notes que se quiere colar algún fantasma, examina la cerradura, da dos vueltas a la llave y vuelve la espalda.

El fantasma será insinuante, expresivo. 
Pretenderá decirte muchas cosas. No hagas caso de sus invitaciones, de sus solicitudes, de sus argucias, de su llanto: lo que él quiere es envenenarte el día.

Dirás acaso que con tener condenada la puerta del castillo escaparías para siempre... Mas debo advertirte que en ese castillo moran también las imaginaciones alegres, los pensamientos joviales que nos hacen llevadero el camino, y la ciencia está en dejar a estos libre la puerta y en impedir a los otro la salida...

¡Qué admirable es la llave de oro que cierra cuidadosamente y a su tiempo la puerta del castillo donde viven los fantasmas!...

(OCAN II: 1045. Cursivas mías).

En el plano esotérico, la llave es uno de los símbolos de la iniciación para acceder a un estado, a una morada espiritual o a un grado en la escala de una logia o de una fraternidad. Pero ese simbolismo está ligado "evidentemente a su doble papel de apertura y de cierre. Es a la vez un papel de iniciación y de discriminación, lo que indica muy claramente al atribuirle a San Pedro las llaves del "Reino de los Cielos" (Chevalier 1982: 261). El segundo objeto simbólico es el castillo, sitio cerrado y a menudo inaccesible y misterioso, que encierra dentro de sus muros un objeto deseado como el Santo Grial, o que protege de los peligros del mundo exterior.

El texto, que se apoya esencialmente sobre estos valores, es una puesta en imágenes alegóricas de la lucha interior del hombre que debe sobrepasar sus temores y sus sufrimientos para que triunfen la esperanza y la fe en el porvenir. Los enemigos son una muchedumbre de "fantasmas negros" que moran en el castillo de "la Pena, de las Imaginaciones dolorosas, de los Miedos sin razón, de las Angustias sin objeto...”. Los nombres, con mayúsculas, de estos estados anímicos negativos, procedimiento de esencialización, recuerdan también las alegorías de ciertos textos de la Edad Media como el Roman de la Rose (1230-1275) en Francia, en los cuales los sentimientos como el amor o los celos, se representaban por medio de objetos simbólicos. Aquí, en la enumeración anterior, Nervo se sirve de una construcción con cuatro elementos, presente en otras partes del breve texto: "el tumulto de las tristezas, de los temores, de las preocupaciones, de la pasión de ánimo"; "no hagas caso de sus invitaciones, de sus solicitudes, de sus argucias, de su llanto". Pero estas construcciones paralelísticas recurren no a un procedimiento de gradación sino más bien a uno de acumulación de sinónimos o de palabras que se van encadenando una a otra, creando un 
sistema de analogías, para reforzar el valor alegórico de la llave y del castillo. Sin embargo, un detalle parece desentonar dentro del conjunto. Se trata de los verbos que caracterizan a los fantasmas y de la actitud que hay que adoptar frente a ellos. En efecto, "tiran de las hojas con toda su fuerza para abrir la puerta, luego se van colando" y la lucha, en lugar de cobrar una dimensión épica, se convierte en "gimnasia" y degenera en gestos rápidos para esquivar "los movimientos astutos de la turba negra". Como si fuera un entrenador deportivo, el narrador aconseja "lo esencial es ser rápido en los movimientos", para adquirir agilidad y alcanzar la verdadera "ciencia", de manera que sólo los buenos fantasmas puedan salir, ¡mientras que los malos queden encerrados con llave! Asistimos entonces a un procedimiento paródico, engendrado por la mezcla de tonos y la introducción de elementos anacrónicos en un texto que empezó con visos alegóricos.

Esta parodia refleja bastante bien la gran confusión de ideologías y de escuelas filosóficas que caracterizaban este sorprendente comienzo de siglo, al mismo tiempo que una relación lúdica para con la escritura, un atisbo de humor y un distanciamiento, expresados con anterioridad en el Nervo periodista. Lo que empezó como una alegoría de las tendencias contradictorias del ser humano, que a ratos lo impulsan y a ratos lo paralizan, acaba con expresiones prosaicas que aconsejan la práctica del auto control, como si tratara de hacer su gimnasia cotidiana. Cansinos Assens ya lo había analizado muy finamente al hablar de la contaminación entre espiritualismo e "higienismo" en Plenitud:

Lo notable es que estos libros recogen los gritos optimistas de la ciencia europea, jubilosa de su Higiene y de su Terapia [...]; marcan, pues, un renacimiento de los paganos gimnasios que coronan las sierpes esculapias, y, sin embargo, se nutren de la antigua alma oriental de la madre alma india, cuyas creencias en los poderes espirituales, en la omnipotencia maravillosa de la voluntad, presta a estos optimismos europeos la más grande capacidad de esperanza. [...] Duchas, gimnasia, en ocasiones vegetarianismo y un ejercicio de la voluntad - se ha pensado--, pueden devolvernos la belleza de la estatua antigua que lloraba Goethe (Cansinos 1919: 38-39).

En este texto, desgraciadamente, Nervo no evita el escollo del discurso didáctico y sus alegorías iniciales pierden su carácter poético para caer en unas estampas neogóticas, muy del gusto de aquella época. 
El texto se desmejora, y se coloca en total desfase con el objetivo poético del comienzo. La intertextualidad que permitió a un texto como "Los pasos" conservar su "poeticidad" no funciona en éste, a pesar de su forma circular, y del uso de la retórica, ninguna tensión se desprende, pues el narrador no instaura una relación antitética con el mundo, y se conforma con suministrar consejos para adquirir una visión positiva, por medio de un lenguaje donde las expresiones alegóricas se codean con expresiones triviales. De modo que la llave, símbolo privilegiado de la iniciación, cabe perfectamente dentro de la temática del libro, pero la distanciación provocada por el humor de Nervo, debilita el mensaje didáctico, sin reforzar el poético. No se trata entonces de un poema en prosa, sino de una reflexión metapoética, bastante inhabitual dentro del libro.

\section{ConClusión}

A raíz de estos análisis y tomando en cuenta el descubrimiento de las fuentes de algunos textos de Plenitud, parece difícil seguir plantéandose el problema de la clasificación genérica de la obra. Hemos visto que muy pocos textos pueden catalogarse como poemas en prosa (tres o cuatro sobre sesenta), y cómo la intención aforística se pierde ante un objetivo más concreto: el deseo de construir un breviario cuyo hilo conductor sería la difusión de una doctrina esotérica, y más exactamente rosacruz. Ahora bien, hemos observado que este mensaje aparece cifrado en el texto de Nervo, ya que viene revestido de un ligero simbolismo masónico, y sus fuentes más aparentes son la filosofía griega, las enseñanzas del estoicismo y la sabiduría oriental. El discurso cristiano, que se asimila fácilmente al de la Rosa Cruz, alude más bien a las virtudes franciscanas y a la imagen de Dios, recordando muy discretamente la simbología de la rosa, omnipresente en dicha doctrina.

Estos aspectos permiten comprender por qué el texto tuvo una acogida muy favorable por parte de los lectores del poeta mexicano, que lo consideraron y lo siguen considerando como un guía espiritual y místico y, de ninguna manera, como un maestro de una sociedad secreta. Posición ésta que, por otra parte, fue duramente atacada por los intelectuales de su época y otros posteriores, y que sigue provocando 
hoy en día algunas críticas negativas. Personalmente deploramos esa evolución del poeta modernista, que acarreó una degradación de su escritura poética a favor de un mensaje doctrinario.

\section{BIBLIOHEMEROGRAFÍA CITADA}

BéCquer, Gustavo Adolfo. Leyendas. Edición de Joan Estruch. Barcelona: Crítica, 1993.

Cansinos Assens, Rafael. Poetas y prosistas del novecientos. Madrid: América, 1919.

Cazenave, Michel. Encyclopédie des symboles. París: Le livre de poche, 1996.

Cernuda, Luis. "Bécquer y el poema en prosa español". En Papeles de Son Armadans, Palma de Mallorca, LVI (noviembre 1960). 123-137.

Chaves, José Ricardo. "Nervo, escritor fantasmático", Texto crítico, 1999.

Chevalier, Jean y Gheerbrant Alain. Dictionnaire des Symboles. París: Robert Laffont, Coll. Bouquins, 1982.

Darío, Rubén. Obras completas. Tomo II. Madrid: Afrodisio Aguado, 1950.

Helguera, Luis Ignacio. Antología del poema en prosa en México. México: Fondo de Cultura Económica, 1993.

KRUMm-Heller, ARNOLD. www.fratreslucis.netfirms.com/Fra01.html

- www.ordenkabalistarosacruz.50megs.com

- www.telepolis.com/agaigcu/biografia HUIRACOCHA.htm

- Rosa esotérica, Buenos Aires, editorial Kier, 1990.

Lamothe, Louis G. Hábleme del modernista mexicano Amado Nervo. Haití: s/e 1962.

Monsiváis, Carlos. Las tradiciones de la imagen: notas sobre poesía mexicana, México: Planeta / Instituto Tecnológico de Monterrey, 2001.

Montandon, Alain. Les formes brèves. París: Hachette, 1992.

Nervo, Amado. Obras completas. México: Aguilar, 1991.

- Plenitude. Trad. al inglés de William F. Ric. Los Angeles, C.A.: Jesse Ray Miller, 1928.

- El castillo de lo inconsciente. (Antología de la literatura fantástica de Amado Nervo). Estudio preliminar de José Ricardo Chaves. México: Consejo Nacional para la Cultura y las Artes, 1999.

- El donador de almas. México: México Moderno, 1920. (La Novela Quincenal).

Othón Robledo, Miguel. "El hombre y el símbolo". En El Pueblo, 8 de julio de 1919.

Reyes, Alfonso. Tránsito de Amado Nervo. Santiago de Chile: Ercilla, 1937. 
Villalpando, Jesús. "El retorno de Amado Nervo". En El Nacional, 7 de julio de 1918, México.

ZERION, F. L. www.club.telepolis.com/agaigcu/rosacruzhermandaddelsaber.htm 